\title{
The Effect of Hypnobreastfeeding Technique on the Production of Breast Milk in Postpartum Mothers in Independent Practice Midwives
}

\author{
Nur Aliyah Rangkuti ${ }^{1}$, Novita Sari Batubara ${ }^{2}$, Rya Anastasya Siregar ${ }^{3}$, Elvi Suryani ${ }^{4}$, Ratna Dewi Siregar \\ Maryam Latifah Harahap ${ }^{6}$ \\ ${ }^{1,2,3 \& 5}$ Health faculty, Aufa Royhan University, Indonesia \\ ${ }^{4 \& 6}$ D3 Midwifery Study Program, Darmais Padangsidimpuan Midwifery Academy, Indonesia
}

\begin{abstract}
Article Info
Article history:

Received December 01, 2021

Revised December 16, 2021

Accepted December 20, 2021

\section{Corresponding Author:}

Nur Aliyah Rangkuti

Health faculty, Aufa Royhan

University Padangsidimpuan,

Padangsidimpuan, Indonesia

nuraliyahrangkuti@gmail.com

ABSTRACT

Breastfeeding is influenced by several factors, including breast milk does not come out immediately after giving birth, the baby's difficulty in sucking, the condition of the mother's nipples being unsupported, the mother working, and the influence/promotion of breast milk substitutes. The purpose of this study was to determine the effect of the hypnobreastfeeding technique on breast milk production in postpartum mothers at BPM Atikah, Panyabungan District. The research design is an analytic experimental preexperimental type with a pretest-post test one group design approach. all postpartum mothers < 24 hours at BPM Atikah as many as 25 postpartum mothers, the sampling technique was total sampling. The results of the research on breast milk production before the hypnobreastfeeding technique was carried out in postpartum mothers were mostly less than $7-123 \mathrm{ml}$ as many as 12 (48\%) and after hypnobreastfeeding in postpartum mothers at BPM Atikah mostly good $>7-123 \mathrm{ml}$ as many as $12(48 \%)$. There is an effect of hypnobreastfeeding technique on milk production with a $\mathrm{p}$ value of $0.001<0.05$. Postpartum mothers should increase their knowledge and experience in an effort to increase breast milk production so that mothers can give breast milk optimally.
\end{abstract}

\section{Keywords:}

Hypnobreastfeeding, breastfeeding, postpartum mothers.

This article is licensed under a Creative Commons AttributionShareAlike 4.0 International License..

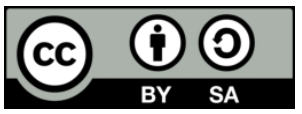

\section{INTRODUCTION}

The World Health Organization (WHO) reports that globally the average rate of exclusive breastfeeding in the world in 2017 was only 38\%, WHO targets that by 2025 the rate of exclusive breastfeeding in the first 6 months of birth will increase by at least 50\%.[19]

Directorate of Family Health in 2019 of 29,322 under-five deaths, 69\% (20,244 deaths) of them occurred in the neonatal period. Of all reported neonatal deaths, $80 \%$ (16,156 deaths) occurred in the first six-day period of life. Meanwhile, $21 \%$ (6,151 deaths) occurred at the age of 29 days - 11 months and $10 \%$ (2,927 deaths) occurred at the age of $12-59$ months.[4][10]

Nationally, the coverage of infants receiving exclusive breastfeeding in 2019 was 67.74\%. The highest percentage of exclusive breastfeeding coverage was in West Nusa Tenggara Province (86.26\%), while the lowest percentage was in West Papua Province (41.12\%). [5][10]

The coverage of babies receiving exclusive breastfeeding in North Sumatra is $50.35 \%$ and the percentage of coverage of infants aged $<6$ months receiving exclusive breastfeeding in Mandailing Natal Regency is $62.5 \%$ or as many as 3,502 babies. [20][24]

Breastfeeding is influenced by several factors, including breast milk does not come out immediately after giving birth, the baby's difficulty in sucking, the condition of the mother's nipples being unsupportive, the mother working, and the influence/promotion of breast milk substitutes. Mother's mental and psychological factors in 
breastfeeding have a very large influence on the breastfeeding process and milk production. Feelings of stress, anxiety and depression experienced by a mother can inhibit milk production. More than $80 \%$ of the failure of breastfeeding mothers to breastfeed is due to psychological factors. There are several ways to stimulate an increase in the oxytocin hormone so that it can overcome the problem of smooth milk production, namely calming yourself down, looking at baby photos, hypnobreastfeeding, warm drinks, stimulating nipples and oxytocin massage. [2][11]

Hypnobreastfeeding is a relaxation technique to help smooth the breastfeeding process, by inserting positive affirmation sentences into the mind when relaxed or in a state of hypnosis. Positive affirmation sentences are expected to help the breastfeeding process. Deep and regular relaxation makes the endocrine system, blood flow, nerves and other systems in the body function better. Maintaining a positive attitude is very important during breastfeeding. Because relaxing while breastfeeding causes the endorphin hormone produced by the mother to flow to the baby through the ASl, and makes the baby also feel comfortable and calm.[6][12][18]

Masrifa's research at BPM Husniyati and BPM Yuhana Palembang City showed that there was an effect of hypnobreastfeeding technique on breast milk production in postpartum mothers with the result $=0.000(\rho<0.05)$, which means that there is an effect of hypnobreastfeeding technique on breastfeeding in postpartum mothers. [8][17]

Research by Endah, et al, in Yogyakarta showed that of 27 respondents who received hypnobreastfeeding treatment, $70.4 \%$ succeeded in providing exclusive breastfeeding. Meanwhile, 30 respondents in the group without hypnobreasfeeding only $43 \%$ gave exclusive breastfeeding.

The results of a preliminary study through interviews on Tuesday, February 9, 2021 with 15 postpartum mothers at BPM, 9 postpartum mothers complained that their breast milk did not come out and planned to give formula milk and had never done hypnobreasfeeding techniques. The purpose of this study was to determine the effect of hypnobreastfeeding on breastfeeding mothers in postpartum mothers at BPM Atikah, Panyabungan District.[9][14]

\section{METHOD}

The research design is an analytic experimental pre-experimental type with a pretest-post test one group design approach. This research was conducted at BPM Atikah, Panyabungan District, Mandailing Natal Regency in January 2021 on the grounds that it was found postpartum mothers with problems with breast milk not wanting to come out and the amount was small, which resulted in postpartum mothers wanting to give formula milk for babies and there has never been a research done on how the hypnobreas feeding technique on spending breast milk in postpartum mothers. The sample in this study were all postpartum mothers $<24$ hours at BPM Atikah as many as 25 postpartum mothers. By using a total sampling technique, all members of the population were used as the research sample, totaling 25 people.[15][16][28]

Bivariate analysis was carried out using a dependent $\mathrm{T}$ test to identify breast milk production before and after performing the hypobreastfeeding technique through pre-test and post-test in order to obtain a significant value indicated by p-value $<0.05$.[20]

\section{RESULTS AND DISCUSSION}

Table 1. Frequency Distribution of Postpartum Mothers (Age and Parity) at PBM Atikah Sipolu-Polu

\begin{tabular}{|c|c|c|}
\hline $\begin{array}{l}\text { Characteristics of Postpartum } \\
\text { Mothers }\end{array}$ & $\mathbf{n}$ & $\%$ \\
\hline \multicolumn{3}{|l|}{ Age } \\
\hline$<20$ years & 2 & 8 \\
\hline 20-35years & 20 & 80 \\
\hline$>35$ years & 3 & 12 \\
\hline \multicolumn{3}{|l|}{ parity } \\
\hline Primipara & 8 & 32 \\
\hline Multipara & 12 & 48 \\
\hline Grandemultipara & 5 & 20 \\
\hline Total & 25 & 100 \\
\hline
\end{tabular}

Based on table 1, the results showed that the majority of postpartum mothers were at the age of 20-35 years as many as 20 people $(80 \%)$ and a small part at the age of $<20$ years as many as 2 people (8\%). Most postpartum mothers with parity multipara as many as 12 people (48\%) and a small proportion of pregnant women with parity grandemultipara as many as 5 people (20\%). 
Table 2. Distribution of the Frequency of Breastfeeding for Postpartum Mothers Performed Hypnobreastfeeding Techniques Pre-test and Post-test at PBM Atikah Sipolu-polu

\begin{tabular}{|c|c|c|}
\hline Postpartum breast milk production & $\mathbf{n}$ & $\%$ \\
\hline \multicolumn{3}{|l|}{ Pre test } \\
\hline Good $>7-123 \mathrm{ml}$ & 4 & 16 \\
\hline Enough 7-123 ml & 9 & 36 \\
\hline Not enough $<7-123 \mathrm{ml}$ & 12 & 48 \\
\hline \multicolumn{3}{|l|}{ Post test } \\
\hline Good $>7-123 \mathrm{ml}$ & & 48 \\
\hline Enough 7-123 ml & 7 & 28 \\
\hline Not enough $<7-123 \mathrm{ml}$ & 6 & 24 \\
\hline Total & 25 & 100 \\
\hline
\end{tabular}

Based on table 2, the results of the study show that before (pre-test) the hypnobreastfeeding technique was performed on 25 postpartum mothers, most of the milk output was less $<7-123 \mathrm{ml}(48 \%)$ and a small portion of good milk output was $>7-123 \mathrm{ml}$ for 4 people. (16\%).

Hypnobreastfeeding technique was applied to 25 postpartum mothers, most of them were expressing good milk $>7-123 \mathrm{ml}$ as many as $12(48 \%)$ and a small proportion of breastfeeding was less <7-123 $\mathrm{ml}$ as many as 6 people (24\%).

Table 3. Test for Normality of Breastfeeding for Post-partum Mothers Pre-test and Post-test at BPM Atikah

\begin{tabular}{cccc}
\multicolumn{3}{c}{ Kolmogorov-Smirnov Z } \\
\hline n & Mean & Std. Deviation & $\begin{array}{c}\text { Asymp. Sig. (2- } \\
\text { tailed) }\end{array}$ \\
\hline 25 & $\begin{array}{c}0,00000 \\
00\end{array}$ & 0,70394298 & 0,517 \\
\hline
\end{tabular}

Based on table 3 shows the results of the normality test using the Kolmogorov-Smirnov Z with a sample size of less than 50 postpartum mothers, indicating that there is data that is normally distributed where $\mathrm{p}$ value $=0.517>$ from 0.05 .

Table 4 Paired Samples T-Test The Effect of Hypnobreastfeeding Techniques on Breastfeeding Expenditure in Postpartum Mothers at BPM Atikah

\begin{tabular}{|c|c|c|c|c|c|}
\hline \multirow{3}{*}{ Kelompok } & \multicolumn{5}{|c|}{ Paired Differences } \\
\hline & \multirow{2}{*}{ Mean } & \multirow{2}{*}{ Std. Deviation } & \multicolumn{2}{|c|}{ 95\% Confidence Interval } & \multirow{2}{*}{$p$ value } \\
\hline & & & Lower & Upper & \\
\hline $\begin{array}{l}\text { Pre test - } \\
\text { Post test }\end{array}$ & 0,56000 & 0,76811 & 0,24294 & 0,87706 & 0,001 \\
\hline
\end{tabular}

Based on table 4, the results of the Paired Samples T-Test analysis conducted on 25 postpartum mothers showed that the average (mean) was 0.56000 , the standard deviation value was 0.76811 , while the difference in the lowest value was 0.24294 and the difference was 0.24294 . the highest value is at a score of 0.87706 , based on this value it can be concluded that at the $95 \%$ confidence level there is a difference in breast milk production after the hypnobreast feeding technique with $\mathrm{p}$ value $=0.001<=0.05$, then there is an effect of hypnobreast feeding technique on expenditure Breastfeeding at BPM Atikah

\subsection{Characteristics of Postpartum Mothers (Age and Parity) at BPM Atikah}

Respondents in this study were postpartum mothers at BPM Atikah with a total of 25 respondents. The description of the characteristics shows that most of the postpartum mothers are at the age of 20-35 years as many as 20 people $(80 \%)$ and a small number at the age of $<20$ years as many as 2 people $(8 \%)$.

The results showed that the respondent's age was in the healthy category. postpartum mothers are ready to produce breast milk, the age of postpartum mothers can affect milk production, where the age of postpartum mothers who are still easy to produce more breast milk than older mothers.

The results of this study are in line with Masrifa's research where most of the age of postpartum mothers are at the age of 22 and 25 years with the number of respondents being $4(13.3 \%)$, while the least number of respondents is at the age of 19, 26, 33, and 36 with the number of respondents 1 (3.3\%).[15]

Most of the pregnant women with parity multigravida as many as 12 people (48\%) and a small proportion of pregnant women with parity grandemultigravida as many as 5 people (20\%). This study is different from the results obtained by Rusmita, most respondents do not have a history of parity (nullipara) of $60.4 \%$. 
The number of deliveries that the mother has experienced provides experience in giving breast milk to the baby. The more parity the mother will be more experienced in breastfeeding and know how to increase milk production so that there is no problem for mothers in breastfeeding.

The results of this study are in line with Sari's research where the parity of most of the respondents is multi parity (had given birth more than 1x) in the intervention group as many as 19 respondents $(63.3 \%)$, and in the control group as many as 18 respondents $(60 \%)$.

\subsection{Breastfeeding Expenditure on Post Partum Mothers Pre-test and Post-test using Hypnobreastfeeding Techniques at BPM Atikah}

The results showed that the postpartum mother's milk output before the hypnobreastfeeding technique was carried out on 25 postpartum mothers, most of them were less than 7-123 ml of breast milk (48\%) and a small proportion of good breast milk was $>7-123 \mathrm{ml}$ of 4 people $(16 \%)$. And breastfeeding contests for postpartum mothers before (post test) were carried out on 25 postpartum mothers, most of them were good breastfeeding contests $>7-123 \mathrm{ml}$ as many as $12(48 \%)$ and a small proportion of less than $7-123 \mathrm{ml}$ breastfeeding contests as many as 6 people (24\%) .

The results of this study indicate that by using the hypnobreastfeeding technique, the mother can become calmer and more relaxed, thereby increasing the hormone oxytocin and producing the volume of milk in postpartum mothers. Hypnobreastfeeding technique should be done before breastfeeding. The decrease in breast milk production in the first days after giving birth can be caused by a lack of stimulation of the hormones prolactin and oxytocin which play a very important role in the smooth production of breast milk.

The hypnobreastfeeding technique is a natural effort that is carried out using therapy by giving positive suggestion sentences so that while breastfeeding there are no obstacles in the production of breast milk. By using sentences of positive and motivating suggestions when the mother's condition is calm and focused on a thing/hypnotic state so that the milk produced will be able to meet the needs of her baby. [11]

The results of this study are in line with Masrifa's research where breastfeeding before the intervention was given was in the moderate category, namely 23 respondents $(76.7 \%)$. Meanwhile, the smallest amount of breast milk expenditure with a small category is 7 respondents $(23.3 \%)$ and most of the breastfeeding expenditure after the intervention is in the large category is 21 respondents $(70.0 \%)$. While the smallest amount of breastfeeding with the least amount is 2 respondents $(6.7 \%)$. [15]

The results of this study are also in line with Hanum where the expulsion of breast milk in postpartum mothers before (pre-test) hypnobreastfeeding was carried out on 30 respondents, the majority of whom had abnormal breast milk, namely 27 people (90\%), and normal breastfeeding minors as many as 3 people (10\%) and the expulsion of breast milk in postpartum mothers after (post test) the hypnobreastfeeding technique was carried out with 30 respondents with the majority of normal breastfeeding being 27 people (90\%) and a minority of abnormal breastfeeding being 3 people (10\%). [9]

The results of this study indicate that by using the hypnobreastfeeding technique, the mother can become calmer and more relaxed, thereby increasing the hormone oxytocin and producing the volume of milk in postpartum mothers. According to the researcher's assumption, the hypnobreastfeeding technique should be done before breastfeeding.

\subsection{The Effect of Hypnobreastfeeding Techniques on Breastfeeding Production for Postpartum Mothers at BPM Atikah}

The results of the Paired Samples T-Test analysis conducted on 25 postpartum mothers showed that the average (mean) was 0.56000 , the standard deviation value was 0.76811 , while the difference in the lowest value was 0.24294 and the difference in the highest value was 0.24294. at a score of 0.87706 , based on this value, it can be concluded that at the $95 \%$ confidence level there is a difference in breast milk production after the hypnobreastfeeding technique with $\mathrm{p}$ value $=0.001<=0.05$, then there is an effect of the hypnobreastfeeding technique on breastfeeding at BPM Atikah.

The results of this study illustrate how to control the mind of a postpartum mother because if the mother's intentions and thoughts are consistent to breastfeed her baby and always think about positive values, the support of her husband and family makes it possible to achieve exclusive breastfeeding for a minimum of six months. mother. The hypnobreastfeeding technique will provide a way out in the process of solving problems in the production of breast milk, and will be able to overcome obstacles in the breastfeeding process.

The results of this study are in line with Arianti where the results using the T test show that $\mathrm{p}$ value $=0.000<$ 0.005 , meaning that there is a relationship between hypnobreastfeeding and breast milk production of $0.000<0.005$, meaning that there is an effect of hypnobreastfeeding technique on milk production at Sumiariani Clinic Medan. [2]

Hypnobreastfeeding really helps breastfeeding mothers to give positive suggestions that she is able to breastfeed her baby well. [13]

Hypnobreastfeeding is a natural effort to use subconscious energy so that the breastfeeding process runs comfortably smoothly, and mothers can produce breast milk that meets the baby's needs by including positive affirmative sentences for the breastfeeding process when the mother is very relaxed or very concentrated. [7]

This study is in accordance with Pratiwi's research which states that increasing breast milk production can be done with hypnobreastfeeding which is proven to be able to increase milk production where $\mathrm{p}<0.005$ means that there is an effect of hypnobreastfeeding techniques on increasing breast milk production. [20]

Int Jou of PHE 
This result is also in line with Ruslinawati's research where there is a difference in the production of breast milk in the control group and the intervention group with the results of the paired simple t-test $(\mathrm{T}$ test $) \mathrm{p}<0.000$ where there is an effect of hypnobreastfeeding on breast milk production.[22]

\section{CONCLUSION}

The conclusions in this study are:

1. Breast milk production before the hypnobreastfeeding technique was performed on postpartum mothers at BPM Atikah was mostly less than 7-123 ml as many as $12(48 \%)$.

2. Breastfeeding output after hypnobreastfeeding for postpartum mothers at BPM Atikah was mostly good $>7$ $123 \mathrm{ml}$ as many as $12(48 \%)$.

3. There is an effect of hypnobreastfeeding technique on breast milk production at BPM Atikah with $\mathrm{p}$ value $0.001<0.05$.

Suggestions in this research are:

1. For Research Places. BPM Atikah can improve health services for mothers and babies by providing hypnobreastfeeding techniques for post-partum mothers, and can be developed as part of caring for mothers and children at BPM Atikah.

2. For the Mandailing Natal District Health Office. The Mandailing Natal District Health Office should provide infrastructure for breastfeeding corners so that breastfeeding activities for babies can run and the implementation of exclusive breastfeeding can be achieved according to national targets.

3. For further researchers. For further researchers, it is recommended that this research be developed with other methods so that further research is more perfect

\section{ACKNOWLEDGEMENTS}

Author thanks Novita Sari Batubara, Rya Anastasya Siregar, Elvi Suryani, Ratna Dewi Siregar Maryam Latifah Harahap. In most cases, sponsor and financial support.

\section{REFERENCES}

[1] Aggraini, Y "Postpartum Midwifery Care", Jakarta: EGC, 2017.

[2] Arianti, V "Relationship between hypnobreastfeeding and breast milk production at sumiariani clinic Medan", Undergraduate, Ministry of Health. Health Polytechnic, Medan, Indonesia, 2017.

[3] Ambarwati, E. R., "Postpartum Midwifery Care", Jogjakarta: Mitra Cendikia, 2016.

[4] Andriana.E, "Painless Childbirth", Jakarta: PT Bhuana Ilmu Populer, 2016.

[5] Aprilia, "Hypnobreastfeeding Smart Solution to Increase Breast Milk Production", 24 Januari 2021. http://ww.bidankita.com/?s = Hypnobreastfeeding \%2C+Solusi +Cerdas+Meningkatkan+Produksi+ASI.

[6] Armini, NW, "Hypnobreastfeeding is the Beginning of the Success of Exclusive Breastfeeding," 24 Januari 2021. [7]https://www.google.co.id/url?sa=t\&rct=j\&q=\&esrc=s\&sour=web\&cd=1\&cad=rja\&uact=8\&ved=0ahUKEwi77LCVxNnYAhVGGx6sQFgg kMAA

[7] Astin, "Mind-Body Medicine", State Of The Science, Implications For Practice. J Am Board Fam Pract, 2016

[8] Evariny, "Smooth breastfeeding with hypnobreastfeeding", 26 Januari 2021 http://www.hypnobirthing. web.id/?p=559, 2016

[9] Hanum, dkk, "The Effect of Hypnobreastfeeding on Breastfeeding Expenditure in Postpartum Mothers at the City Health Center," Scientific Journal of Midwifery Imelda. Vol.7, No.1, 2021

[10] Kemenkes RI. "Indonesian Health Profile”, 2019.[2020] , Minister of Health, Jakarta, Republik Indonesia.

[11] Kuswandi, "Smooth Breastfeeding with Hypnobreastfeeding", 24 Januari 2021, http://anakibu.haryp.com/ibu/asi-lancar dengan hypnobreastfeeding. 2017

[12] Maritalia, D, "Postpartum and Breastfeeding Midwifery Care", Yogyakarta :Pustaka Pelajar, 2016.

[13] Marmi, "Midwifery Care During Puerperium Care", Yogyakarta :Pustaka Pelajar, 2018.

[14] Maryunani, A, "Early Initiation of Exclusive Breastfeeding and Lactation Management”, Jakarta : CV Trans Info Media, 2016

[15] Masrifa, E, "The Effect of Hypnobreastfeeding Techniques on Breast Milk Production in Postpartum Mothers at BPM Husniyati and BPM Yuhana Palembang City”, Undergraduate, Ministry of Health. Health Polytechnic Palembang, Indonesia. 2018.

[16] Monika, F. B, "Breastfeeding and Breastfeeding Smart Book", Jagakarsa: PT Mizan Publika, 2017.

[17] Notoatmodjo, "Health Research Methodology", Jakarta: PT Rineka Cipta, 2017.

[18] Nursalam, "Concept and Application of Nursing Research Methodology: Nursing Research Instruments", Jakarta: Salemba Medika. 2017

[19] Organization, World Health. 2017. World health statistics 2017. World Health Organization.

[20] Pratiwi, Y. S, "Effect of Hypnobreastfeeding on Breast Milk Production", Qamarul Huda Kesehatan Health Journal Vol. 6, No. 2. 2018.

[21] Ruslinawati, H, dkk, "The Effect of Hypnobreastfeeding on Breast Milk Expenditure in the Work Area of the Banjarmasin Health Center", Journal of Nursing Carling, Vol. 2, No. 2. 2019

[22] Roesli, U, "Exclusive breastfeeding", Jakarta: Republic National Library Of The Republic Of Indonesia, 2016.

[23] Roesli, U.Yahmi, E, "Lactation Management", Jakarta: IDAI, 2016.

[24] Siregar, A, "Exclusive breastfeeding and the factors that influence it", Medan:FKM USU, 2004.

[25] Soetjiningsih, D, "Breastfeeding Instructions for Health Workers", Jakarta: EGC, 2018.

[26] Sunarti,S, "Practical and Complete Breastfeeding Guide", Jakarta : PT Sunda Kelapa, 2016

[27] Sulistyawati, A, "Textbook of Midwifery Care for Postpartum Mothers", Yogyakarta : Andi, 2018.

[28] Sugiyono, "Quantitative, Qualitative and R\&D Research Methods", Bandung : Alfabeta, 2019.

[29] Walyani, ES. Purwoastuti, TE," Postpartum and Breastfeeding Midwifery Care", Yogyakarta : Pustaka Baru Press, 2018 